\title{
Political Effect on Major Transport Elements of Budapest after the Transition
}

\author{
G. Gaal, Á. Török* \\ Institute for Transport Sciences Non-profit Ltd, Division for Transport Policy and Economics, Budapest, Hungary \\ * Corresponding author: torok.adam@kti.hu
}

DOI: $10.2478 / \mathrm{v} 10158-012-0015-2$

\begin{abstract}
The aim of our article is to describe the connection between the Hungarian political environment and the development of the transport system of the Hungarian capital, Budapest, since the beginning of economic transition. The starting point of our research is the beginning of the transitions as from this period the political parties had the chance to make changes in the transport sector in order to build a liveable city. The authors have reviewed the urban transport programs of the parties, which they planned to realize in the case of winning the elections. The authors have dealt only with parties which were present in the Parliament during all parliamentary periods since 1990. The authors have investigated four parameters: length of express roads and the length of the M0 ring road as a parameter of economic growth and development, service levels (length of services, average age of vehicles, number of vehicles) of BKV (a monopoly responsible for urban transport in Budapest) and the length of cycle paths.
\end{abstract}

KEY WORDS: transport policy, urban mobility, Budapest.

\section{INTRODUCTION}

The aim of the authors was to investigate the transport policy of the Hungarian capital, Budapest. The starting point of our research is the beginning of the transition of the Hungarian political regime as, from this period on (after having been formed) the political parties had the chance to express their views on the topic. The authors have reviewed the plans regarding transport incorporated into the electoral programs of the parties, which they wished to realize in the case of winning the elections.

The authors have only dealt with parties which were present in the Parliament in all parliamentary periods since 1990, i.e., the beginning of financial transition. These were in order of governance - the Hungarian Democratic Forum (MDF), the Hungarian Socialist Party (MSZP), the Alliance of Free Democrats (SZDSZ), and the Alliance of Young Democrats (Fidesz). The aim was to review the electoral programs and also the programs of the governments if they contained something in relation to transportation in Budapest.

The authors wanted to compare the main elements of the programs and, following that, with the help of quantitative data to compare the programs with the realized changes. (The authors always counted the years of elections up to the final governmental period.) A 20-year long evolution of four significant factors influencing the transport in Budapest has been charted: the expansion of the motorway-network - increasing the traffic of the capital, the construction of the M0 ring-road - decreasing the traffic in the capital, 
the number and the mean age of the vehicles of Budapest Transport Limited (BKV, the public transport company of Budapest) - increasing the attractiveness of public transport, and the length of the capital's bicycle track - decreasing passenger transport within the inner city.

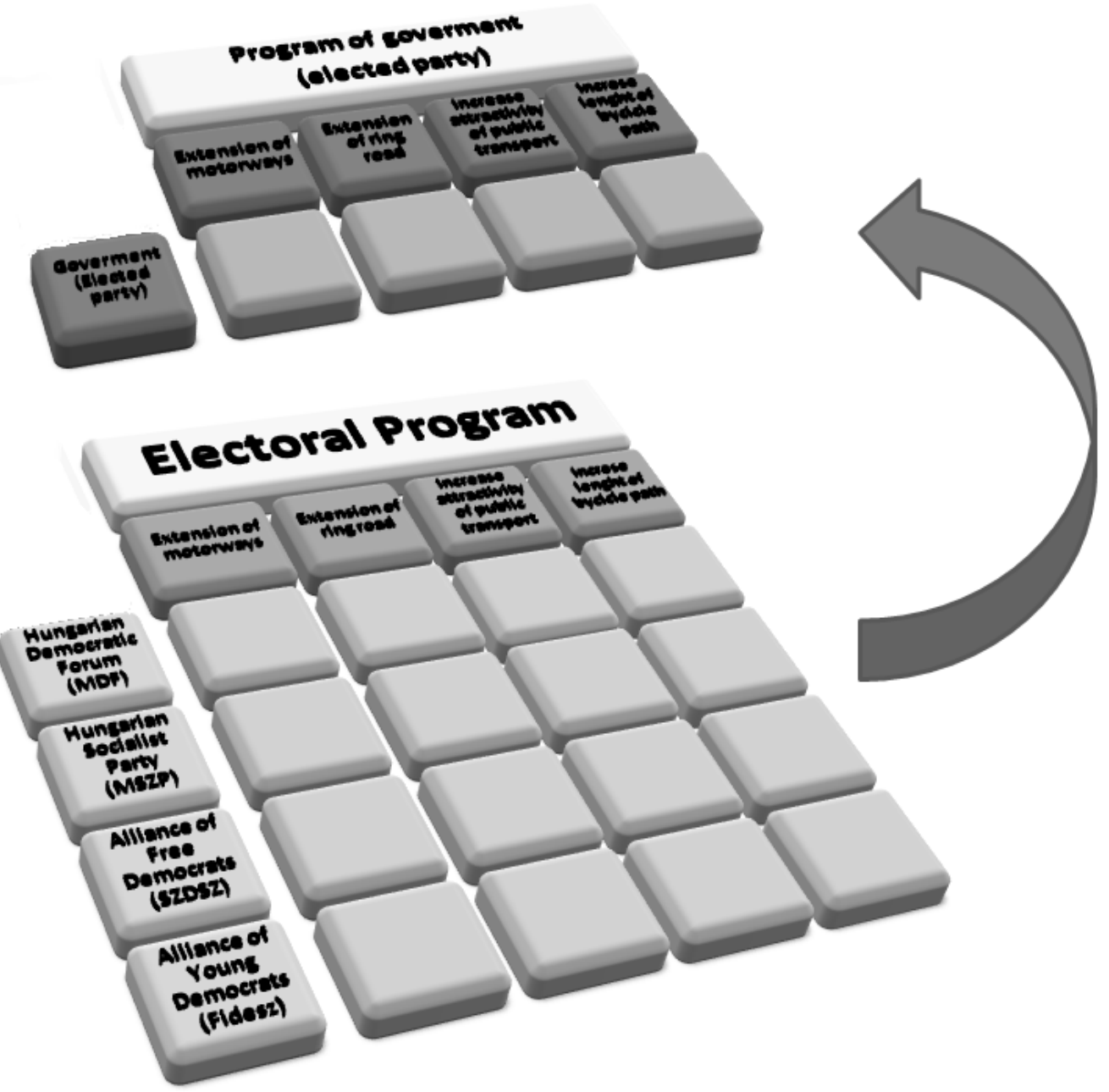

Figure 1: Area of investigation.

(Source: own research)

The European Union realizes its responsibility and opportunities: "urban mobility policies need to be based on an approach which is as integrated as possible, combining the most appropriate responses to each individual problem: technological innovation, the development of clean, safe, and intelligent transport systems, economics incentives, and amendments to legislation" (Green Paper, 2007).

\section{MOTORWAY-NETWORK}

Why do we need to handle the motorway-network and the M0 ring-road in Hungary if the subject of the paper is urban mobility? The question can be answered easily we can find a big challenge in the background. "Congestion in towns and cities is one of the main problems [...]. It is often located on urban ring roads and affects the capacity of the TransEuropean Transport Network (TEN-T)” (Green Paper, 2007). It is also true for Budapest 
that the congestion damages the state's and the European Union's economic interests. TEN-T is the European transport network created from the member states' own networks.

In 1990 the MDF wanted to increase the speed of motorway construction. Beside this, it would have liked to see the radial network transformed into a ringed network (Program of the Hungarian Democratic Forum, 1989). The Fidesz found that either: the central role of Budapest should be decreased (Program assumed by the II. congress of Fidesz, 1989). The MSZP did not have a written program for this period. The SZDSZ had one but we could not find anything in it in connection with transport. In 1990 the MDF won the elections bu there were two other parties in the coalition government. In their program of governance (Program of the national regeneration, 1990) they emphasized the program of motorway construction which aimed to help the country develop organically. The motorways are one of the most important connections to Europe. The network increased 10.2\% in 1994 (always compared to the last year (Hungarian statistical yearbook 2000)). In 1994 none of the parties mentioned the motorways in their electoral programs. But after the elections in one of the main elements of the MSZP-SZDSZ coalition government's program (Program of the Government of the Republic of Hungary 1994-1998, 1994) the government intended to finish the construction of the motorways. The network increased by $10.6 \%$ in 1996, 3.6\% in 1997 and $16.9 \%$ in 1998 (always compared to the last year (Hungarian statistical yearbook 2000)).

The European Commission welcomed the new parts of the M3 and M5 motorways in its Regular Report on Hungary's progress towards accession (Regular Report from the Commission on Hungary's progress towards accession, 1998). In 1998 only the MSZP dealt with the question of the motorways: it said that Hungary needed motorways that reach the country's borders, and needed them developed in a ringed network (Puch, Soós, 1998). The other three parties did not mention anything in relation to this topic. We can read in the Fidesz-MDF coalitional government's program that they wanted to do everything to increase the speed of motorway construction (Governmental program for the civil Hungary, 1998). In 2000 (Regular Report from the Commission on Hungary's progress towards Accession, 2000) and 2001 the Regular Report on Hungary's progress towards Accession (Regular Report on Hungary's progress towards Accession, 2001), the European Commission notes that even though no new parts were constructed the Hungarian government promised to change that trend and Hungary takes into consideration the aims and priorities of the TEN-T network.

In 1999 and 2002, the motorway network increased by 7.1\% and 11.7\% (compared to the last year (Hungarian statistical yearbook 2007)). The situation in 2002 was quite similar to that of 8 years before: only the new government's (a MSZP-SZDSZ coalition for the second time) program contained something about motorways: they wanted to finish the first section and continue M3 and M5 as a strategic aim (The history of the M0 ring-road, 2010). In 2004 a new prime minister was elected by the parliament who came with a new governance program; this, however, unfortunately did not cover the motorways. Nevertheless the length of the network increased the most in this period: $4.5 \%$ in 2003, $7.5 \%$ in 2004, $12.0 \%$ in 2005 and $20.4 \%$ in 2006 (always compared to the last year (Hungarian statistical yearbook 2007)).

In 2006 we find a new situation: not just the electoral but also the governance programs lack intentions relating to motorways. The last governmental period ended in 2010. The length of the network increased by $7.2 \%$ percent in $2007,7.3 \%$ in $2008,0.4 \%$ in 2009 and $15.4 \%$ in 2010 (always compared to the last year), so the total length of the Hungarian motorway network was $1314 \mathrm{kms}$ in 2010. The results reached in each governmental period can be easily compared with the help of Figure 2 . 


\section{New motorway sections in the governmental periods}

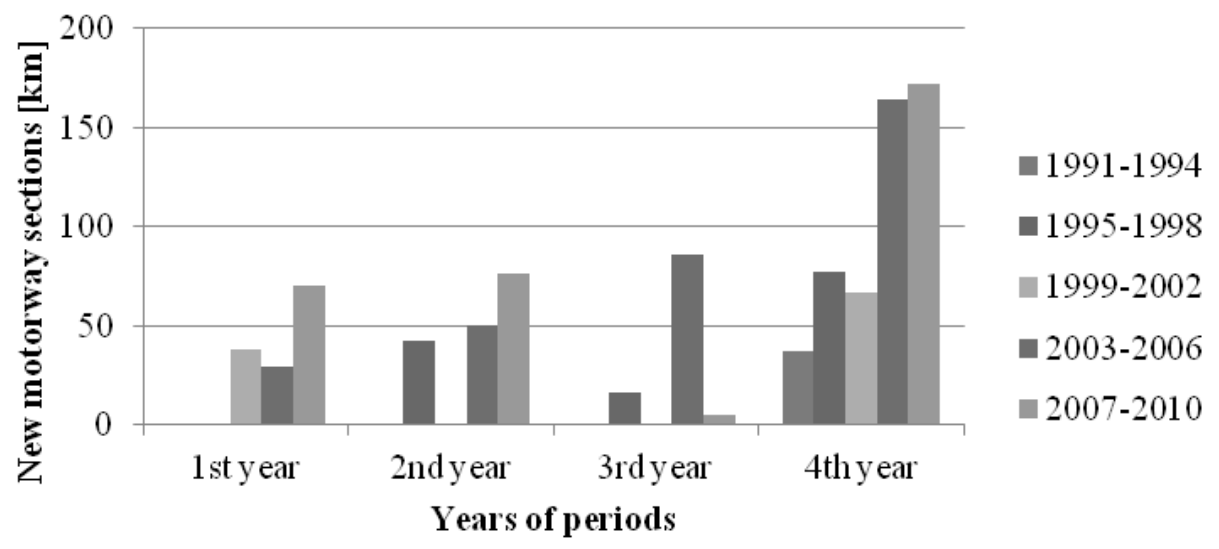

Figure 2: The expansion of the Hungarian motorway-network 1990-2010.

(Source: own research)

\section{THE M0 RING-ROAD}

The construction of the M0 ring-road was started in 1987. The first 6-km-long section was ready in 1988, but the first longer section could only be used from 1990 (The history of the M0 ring-road, 2010). The M0 is only mentioned by the Fidesz where they say the construction of it is necessary (Program assumed by the II. congress of Fidesz, 1989). The other three parties' and the government's program does not cover the ring-road.

In 1993 the new prime minister in his government's program (Governmental program in the terms of continuance, stability, and development, 1993) promises to finish its construction. Following that a 15-km-long section became ready in 1994 (The history of the M0 ring-road, 2010). In the next eight years, from 1994 to 2002 nobody dealt with the question, irrespective of whether the parties prepared for the elections, or were in governmental or oppositionist status. Nevertheless, $6 \mathrm{kms}$ were constructed in 1999 (Motorways of Hungary, 2010).

In 2002, the coalition of Fidesz and the MDF tried to keep their governmental position. Before the elections they promised to complete the M0 ring-road's northern, eastern and southern sectors and to build the northern bridge (The future has begun: electoral program of Fidesz Hungarian Civil Party - MDF, 2002). The MSZP also mentioned the M0, but not in their electoral program, just in a professional transport booklet (Professional debate documents on the change of the welfare system, 2001): the transit traffic and crowdedness of Budapest must be decreased by building the M0 ring-road, and after that by transforming it into a motorway. As it was pointed out earlier, the M0 was mentioned as a strategic aim by the MSZP-SZDSZ coalition in 2002 (Act now and for everybody 2002-2006, 2002), but only a 12-km-long section was constructed in 2005 (Motorways of Hungary, 2010).

In 2006, the Fidesz (Go, Hungary! Program of the active nation, 2006) and the MSZP (Safety, justice, courage, 2006) both promised the construction of the whole M0, and we can find it in the MSZP-SZDSZ coalition's program as well (New Hungary. Freedom and solidarity, 2006-2010). In the last period it has not been finished (and it will not be ready for the time of the next elections in 2014), but the longest newest section has been operational since 2008. 
Recently, we can speak about the lack of the western section, but on the other hand we can see $80 \mathrm{kms}$ is ready (The history of the M0 ring-road, 2010) (Figure 3.).

\section{The history of the Mo ring-road}

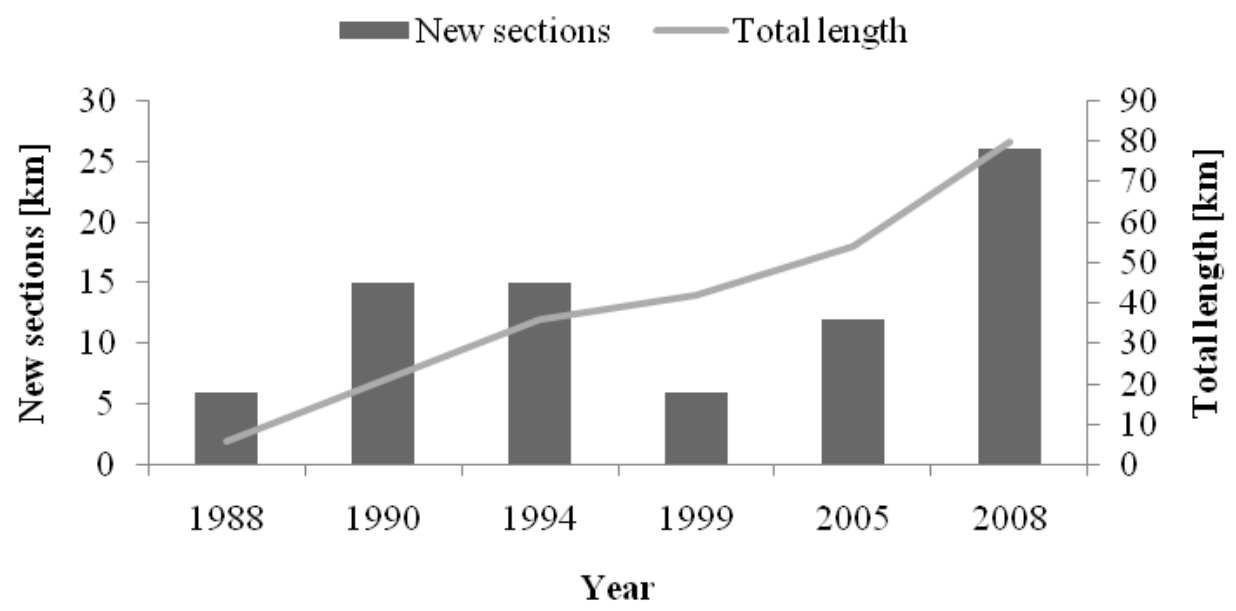

Figure 3: The history of the M0 ring-road

(Source: own research)

\section{THE NUMBER AND THE MEAN AGE OF THE BKV'S VEHICLE FLEET}

In 1990 in the MDF's (Program of the Hungarian Democratic Forum, 1989) and Fidesz's electoral program (Program assumed by the II. congress of Fidesz, 1989) we can read about the advocacy of public transport instead of individual transport modes. They also wanted buses, which pollute the environment less. On the top of this, the program of the government (Program of the national regeneration, 1990) said that many of the vehicles must be changed. In this period 423 buses, 3 trolleys and 10 metro wagons arrived at the company (Yearly reports of the BKV).

In 1994 none of the parties' programs contained anything about public transport; even the new MSZP-SZDSZ government's program omitted it. Nevertheless, 163 buses and 13 trolleys arrived at the company during this period (Yearly reports of the BKV). Only the buses' mean age decreased in 1995.

In 1998 only the MDF (Safety for every day!, 1998) promised something for public transport, namely supporting the purchasing of buses which pollute the environment less. We can read in the Fidesz-MDF coalitional government's program (Governmental program for the civil Hungary, 1998) about developing public transport (buying modern buses). In this period, 115 buses, 15 trolleys and 10 metro wagons were new in the company.

In 2001 BKV bought 76 used trams from Hannover (Yearly reports of the BKV). In spite of having new vehicles the mean age did not decrease significantly. In 2002 again, only the new government's program (Act now and for everybody 2002-2006, 2002) contained a few words about developing and modernizing the stock of vehicles (but after electing a new prime minister in 2004 his new program did not contain it). In this period 150 Volvo buses, 15 trolleys and the first 26 Siemens Combino trams began serving the people in Budapest (Yearly reports of the BKV).

In 2006 only the SZDSZ (Freedom, competition, solidarity 2006-2010) said that if public transport is to be kept alluring, it was necessary to improve its quality. After the elections, these thoughts also permeated the government's program (New Hungary. Freedom 
and solidarity, 2006-2010). The purchase of new vehicles occurred in 2007 and 2009. 14 new Siemens Combino and 10 trolleys (Yearly reports of the BKV) arrived before the company then bought 32 used Belgian buses (Directly from Belgium, 2009). The first Alstom Metropolis metro wagons began their test runs. Of course, many of the oldest vehicles have been junked. We can say that more than $30 \%$ of the vehicles have been changed up to 2008 (compared to the numbers for the year 1990). The mean number of the BKV's vehicles was 2869 in 2008. Fig. 4a and 4b shows the change in the numbers and the mean ages of the BKV fleet.

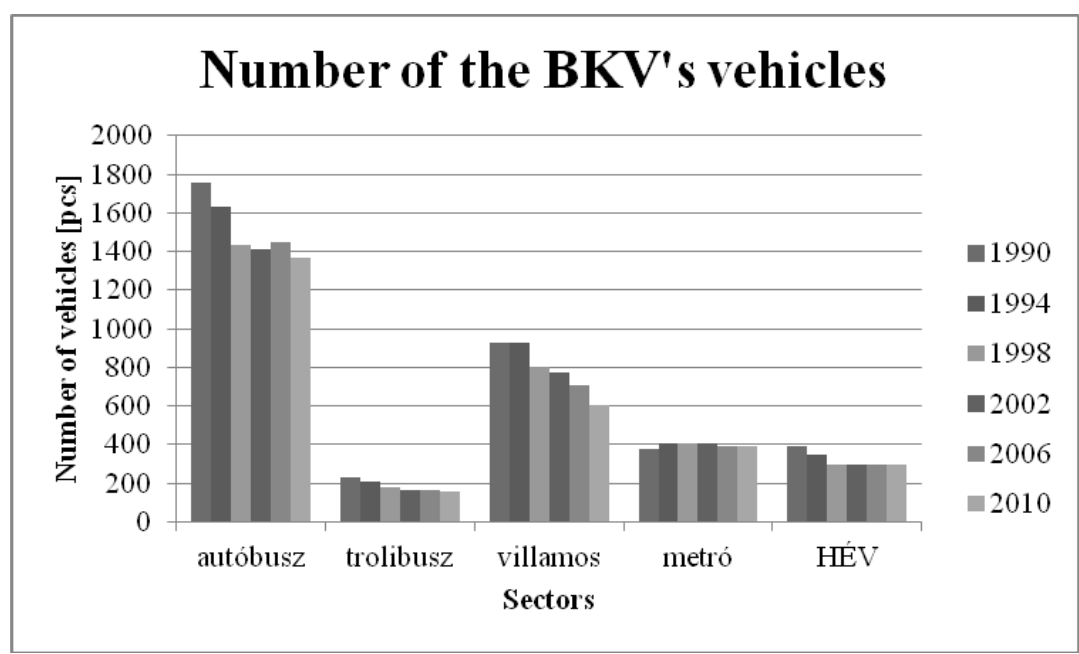

Figure 4a: Number of BKV's vehicles.

(Source: own research)

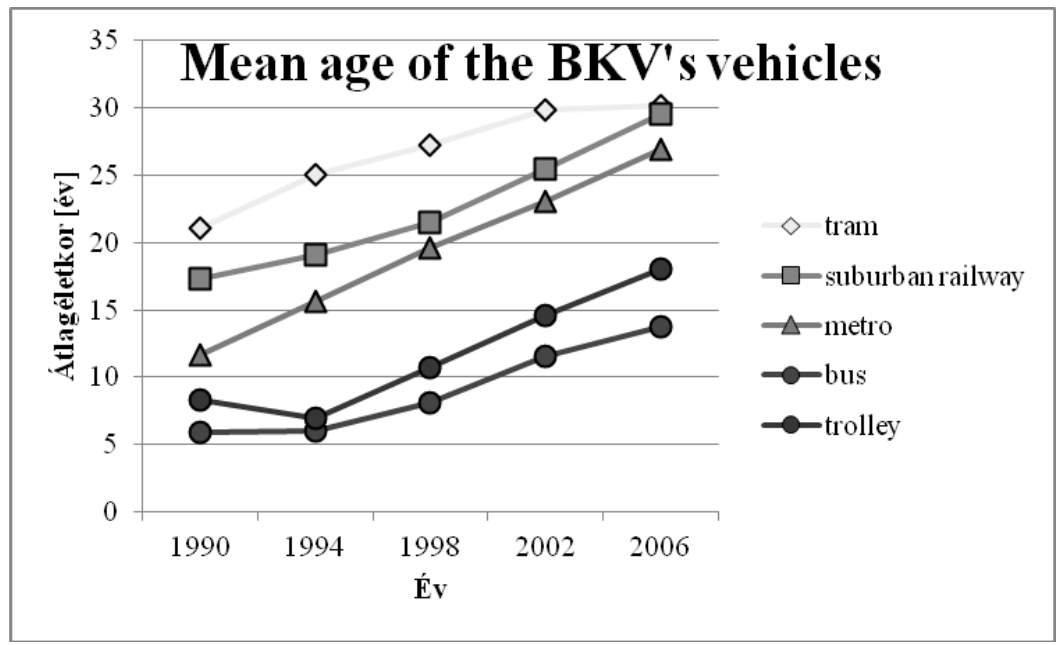

Figure 4b: Mean age of BKV's vehicles.

(Source: own research)

\section{BICYCLE TRACK NETWORK}

The use of bicycles is becoming more popular from year to year. "In the view of stakeholders, improving the perceived safety and security depends on a number of measures in the urban environment. High quality infrastructure, including good pavements for pedestrians and cyclists, can make a difference" (Green Paper, 2007). In 1990 only the Fidesz (Program 
assumed by the II. congress of Fidesz, 1989) handled the question. As they stated in their electoral program, they supported bicycle traffic and they were even ready to support it at the expense of car drivers in the inner parts of cities. After the elections one had to wait for the second government's program (in 1993) (Governmental program in terms of continuance, stability and development, 1993), as it had been promised to build several kms of bicycle track. The data known from this period is that 282 million HUF had been spent on building the track (The capital is committed for the development of the bicycle transport, 2009).

In 1994 none of the electoral and government's programs mentioned the bicycle roads. In spite of this 429 million HUF was spent on constructing new sections. In 1998 the total length of the bicycle tracks reached $100 \mathrm{kms}$ (The capital is committed for the development of the bicycle transport, 2009).

In 1998 the MDF (Safety for every day!, 1998) campaigned with supporting cyclists and pedestrians; the Fidesz (Freedom and welfare, 1998) campaigned with the promise of constructing new tracks. The MSZP's and SZDSZ's programs did not tackle the question. Although the Fidesz and the MDF got the chance to govern in the next four years, unfortunately their program did not contain this task. In spite of this 684 million HUF was spent on constructing new tracks and the total length of the roads almost reached $140 \mathrm{kms}$ (The capital is committed for the development of the bicycle transport, 2009).

In 2002 only the MSZP dealt with the question but none of the electoral and governments' programs mentioned it. As for MSZP, the professional transport booklet (Professional debate documents on the change of the welfare system, 2001) contained it. They point out the necessity of integrating these roads into a network. In this period 215 million HUF was spent on constructing new bicycle roads, and, with this, the total length of the network reached $170 \mathrm{kms}$ (The capital is committed for the development of bicycle transport, 2009).

In 2006 again only one party mentioned the question and this time it was the SZDSZ (Freedom, competition, solidarity 2006-2010, 2006). They stated that the network needed development. In spite of mentioning this, the government's program did not contain these goals. In 2007 and $200817 \mathrm{kms}$ were constructed so that the total length of the network reached $187 \mathrm{kms}$ (The capital is committed for the development of the bicycle transport, 2009). The expansion of the network since 1990 is shown in Figure 5. However, we unfortunately do not have recent data from the last years.

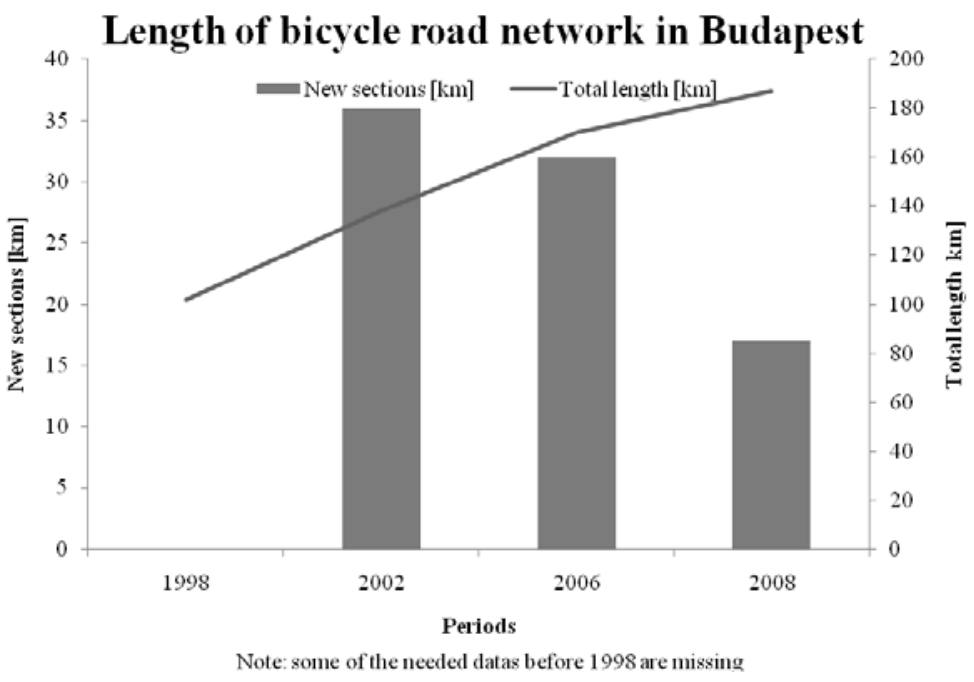

Figure 5: The broadening of the bicycle road network 1998-2008.

(Source: own research) 


\section{SUMMARY}

It can be stated about the Hungarian motorway network that it is four times longer than it was in 1990. The M0 ring-road is still not complete, but has become $80 \mathrm{kms}$ long recently. This development was indispensable in order to decrease the transit traffic and crowdedness of the capital. The development of the expressway system was shelved in time, caused by an unwanted increase in costs.

The network of the BKV expanded during these twenty years, but this result is mainly due to the bus network. Although we have to admit that still too many old polluting vehicles are running on the roads of Budapest, we can regularly come across modernized buses and trams. One third of the vehicles were changed during the twenty years and many of the oldest ones were decommissioned. Still more investment is necessary because most of the financial resources are devoted to the new metro line. All the other public transport modes are suffering from the lack of financial backing. Finally, we can acknowledge that the bicycle road network has been increasing dynamically, although not as a system, but as separated sections have been built. The development of Budapest's transport system has not stopped in these years, as, of course, it could not stop.

\section{REFERENCES}

Act now and for everybody 2002-2006!, 2002. Program of the democratic coalitional Government of the national middle. Hungary 2002-2006. (In Hungarian: Cselekedni, most és mindenkiért! A nemzeti közép, a demokratikus koalíció Kormányának programja. Magyarország 2002-2006.)

Directly from Belgium, 2009. In Mozgásban, Year XLI., Nr. 9. (In Hungarian: Egyenesen Belgiumból.)

Freedom and welfare, 1998. Program of the civil future. (In Hungarian: Szabadság és jólét. A polgári jövő programja, 1998.) Fidesz, 1998.

Freedom, competition, solidarity, 2006-2010. Electoral program of the Alliance of Free Democrats. Proposal accepted by the State-wide Committee for the Envoys' Assembly, 3 December 2005. (In Hungarian: Szabadság, verseny, szolidaritás 2006-2010. A Szabad Demokraták Szövetsége választási programja. Az Országos Tanács által elfogadott javaslat a küldöttgyülésnek, 2005. december 3.)

Go, Hungary! Program of the active nation, 2006. (In Hungarian: Hajrá, Magyarország! A Cselekvő Nemzet Programja. 2006)

Governmental program for the civil Hungary, 1998. On the eve of the new millennium. (In Hungarian: Az új évezred küszöbén. Kormányprogram a polgári Magyarországért. 1998)

Governmental program in the terms of continuance, stability and development, 1993. 20 December 1993. (In Hungarian: Kormányprogram a folyamatosság, a stabilitás és a fejlődés jegyében. 1993. december 20.) 
Green Paper, 2007. Towards a new culture of urban mobility. Brussels: Commission of the European Communities, 25.9.2007. COM(2007) 551 final.

Hungarian statistical yearbook 2000, 2001. Budapest: Central Statistical Office. (In Hungarian: Magyar statisztikai évkönyv 2000. Központi Statisztikai Hivatal, Budapest 2001.)

Hungarian statistical yearbook 2007, 2008. Central Statistical Office. (In Hungarian: Magyar statisztikai évkönyv, 2007. Központi Statisztikai Hivatal, 2008.)

Yearly reports of the BKV [online]. Retrieved from: http://www.bkv.hu/evesjelentes/index.html

Motorways of Hungary [online]. Retrieved from:

http://hu.wikipedia.org/wiki/Magyarorsz\%C3\%A1g_aut\%C3\%B3p\%C3\%A1ly\%C3\%A1i (In Hungarian: Magyarország autópályái)

New Hungary. Freedom and solidarity, 2006-2010. Program of the Government of the Republic of Hungary for a successful, modern and just Hungary 2006-2010. Hungarian Official Bulletin Publisher, Budapest 2006. (In Hungarian: Új Magyarország. Szabadság és szolidaritás. A Magyar Köztársaság Kormányának programja a sikeres, modern és igazságos Magyarországért 2006-2010. Magyar Hivatalos Közlönykiadó, Budapest 2006.)

Professional debate documents on the change of the welfare system, 2001. Professional transport booklet. 21st debate document. November 2001. (In Hungarian: A jóléti rendszerváltás programjának szakmai vitaanyagai. Közlekedési szakmai füzet. 21. vitaanyag. 2001. november)

Program assumed by the II. congress of FIDESZ, 1989. (In Hungarian: A FIDESZ II. kongresszusa által elfogadott program: 1989. október 13-15.)

Program of the Government of the Republic of Hungary 1994-1998, 1994. (Draft) Budapest, 8 July 1994. (In Hungarian: A Magyar Köztársaság Kormányának Programja 1994-1998 (Tervezet). Budapest, 1994. július 8.)

Program of the Hungarian Democratic Forum, 1989. (In Hungarian: Magyar Demokrata Fórum Programja. 1989. október.)

Program of the national regeneration, 1990. The first three years of the Republic. Budapest, September 1990. (In Hungarian: A Nemzeti Megújhodás Programja. A Köztársaság első három éve. Budapest, 1990. szeptember)

Puch, L., Soós, G., 1998. Economic policy of closing up. Professional booklet of economic policy. (In Hungarian: Puch László, Soós Győző: A felzárkózás gazdaságpolitikája. Gazdaságpolitikai szakmai füzet, 1998.)

Regular Report from the Commission on Hungary's progress towards accession, 1998.

Regular Report from the Commission on Hungary's progress towards Accession, 2000. 8 November 2000. 
Regular Report on Hungary's progress towards Accession, 2001. Brussels: Commission of the European Communities, 13.11.2001. SEC(2001)1748.

Safety for every day!, 1998. Program of the Hungarian Democratic Forum (XII. State-wide Assembly, Gödöllő, 1 March 1998.) (In Hungarian: Biztonságot a mindennapoknak! A Magyar Demokrata Fórum Programja (XII. Országos Gyülés, Gödöllő, 1998. március 1.)

Safety, justice, courage, 2006. Electoral program of the Hungarian Socialist Party. (In Hungarian: Biztonság, igazságosság, bátorság. A Magyar Szocialista Párt választási programja. 2006)

The capital is committed for the development of the bicycle transport [online], 2009. Background theme. Local Government of Capital Budapest, Office of the Lord Mayor, 22 September 2009. Retrieved from: http://www.budapest.hu/resource.aspx?ResourceID= kerekpar_fovaros (In Hungarian: A főváros elkötelezett a kerékpáros közlekedés fejlesztése mellett. Háttéranyag. Budapest Főváros Önkormányzata, Főpolgármesteri Hivatal, 2009. szeptember 22.)

The future has begun: electoral program of Fidesz Hungarian Civil Party - MDF, 2002. Budapest, 16 February 2002. (In Hungarian: A jövő elkezdődött: Fidesz Magyar Polgári Párt - MDF választási program 2002. Budapest, 2002. február 16.)

The history of the M0 ring-road, 2010 [online]. Retrieved from: http://www.autopalya.hu/ engine.aspx?page=M0_tortenet (In Hungarian: Az M0 autóút története.) 